\title{
The Practicality and Effectiveness of Direct Learning Model by Using Life-Based Learning Approach
}

\author{
${ }^{*}$ A Kastur ${ }^{1}$, Mustaji ${ }^{1}$, Y Riyanto ${ }^{1}$ \\ 1Universitas Negeri Surabaya, Surabaya Indonesia
}

\begin{tabular}{l}
\hline Article Info \\
\hline Article history: \\
Received November 12, 2020 \\
Revised December 13, 2020 \\
Accepted December 27, 2020 \\
Available Online December 28, \\
2020 \\
\hline
\end{tabular}

Keywords:

Practicality

Effectiveness

Direct Learning

Life Based Learning Approach

\begin{abstract}
This study aims to produce a direct learning model with a life-based learning approach that is feasible, practical, and effective to improve the learning outcomes of students at Morris Sidoarjo. This research method uses the Dick and Carey development model with the onegroup pretest-posttest design research design. The data collection process was carried out using observation, questionnaires, and giving tests to students. The research instruments obtained were student activity questionnaires, student response questionnaires, learning observation sheets, and student learning outcomes tests. The sample of this research is 20 students at the Morris Sidoarjo course. The research indicated that the direct learning model with a life-based learning approach was practical in its use to improve course participants' learning outcomes at Morris Sidoarjo in the Yogyakarta, which was shown by the excellent category of learning and activity of students. Second, the direct learning model with a life-based learning approach is effective in improving the learning outcomes of course participants at Morris Sidoarjo in the Yogyakarta, which is shown by the results of the calculation of the N-Gain test showing an increase in learning outcomes with a value of 0.8 in the high category. From these results, the model built with a life-based learning approach can be implied as an alternative and reference for developing learning models in course institutions.
\end{abstract}

\section{INTRODUCTION}

Consistency in improving students' and teachers' abilities to implement learning outside the classroom determines the quality of education (Hamka \& Arsyad, 2015), both informal and nonformal education (Guttierrez, 2015). In Indonesia, there are several non-formal education that has not received official recognition from the government. However, through several courses and training that has been held by several non-formal institutions, they can help provide the best service in the world of education and support the success of specific skills (Daniel et al., 2020). Education is dynamic (Setiawan, 2020) so it will change depending on global conditions.

The skills possessed by some students have different characteristics; through practical learning, the teacher can convey the objectives of the learning material well (Rachman, 2015). In this 21st century, students and educators must have high creativity to compete in the global world (Aditimo \& Clieme, 2020; Jatmiko et al., 2018). One of the learning materials that require high creativity is learning make-up (Ilmika, 2017). In supporting students' creativity in learning makeup, teacher guidance is needed in every learning process, so that students can produce innovative creations in every drawing technique and design their paintings (Wahyuni \& Prabowo, 2020). 
The direct learning model can provide adequate guidance to students step by step in each learning process (Astutik, 2020; Azwar et al., 2017; Rachman, 2015). Techniques to demonstrate that are effective at each stage will have a good impact on students' obtaining information. Students can obtain this through direct teacher-centered learning (Astutik, 2020). Through several teacher-centered learning stages, it can improve student learning outcomes and students' necessary abilities (Ilmika, 2017; Huet et al., 2011; Al-Faki \& Khamis, 2014). An educator must provide initial training guidance, and must convey information step by step. At the end of the lesson, it is necessary to check students' initial understanding by giving assignments or evaluating together with the learning material that has been delivered (Astutik, 2020).

In obtaining good learning outcomes, a strategy and technique are needed in the learning process. One of the strategies indirect learning is that there is a discussion stage guided by the teacher in each group (Yan et al., 2018). The class discussion process can provide a livelier and more interactive classroom atmosphere (Lecun et al., 2015). Teaching using a learning model with a life basic learning approach can contribute to learning inside and outside the classroom (Daniel et al., 2020). Learning with a life basic learning approach is also able to ensure that what is felt is learned outside the environment can be verified (Miller, 2008; Fatmawati et al., 2019), and can improve students' ability to understand the material (Staron, 2011).

Direct learning using a life-based learning approach provides complete abilities for students; besides this learning is not limited by work. Learning to work and not being limited by work is a hallmark of the life learning approach. Learning outside the classroom can create creative thinking in seeking imagination and self-creation in every work practice (Ilmika, 2017; Hairida, 2018; Hairida 2017). In providing students with initial knowledge in practicing the teacher's work, it is necessary to provide modules relevant to the PowerPoint material (Hamka \& Arsyad, 2015; Abdi, 2014) or student worksheets. This requirement is a medium for student learning resources (Arsyad, 2017). The direct learning model with a life-based learning approach is designed to support student learning outcomes (Daniel et al., 2010; Cheung \& Hew, 2011; Bakare \& Orji, 2019). There is two knowledge conveyed in it, namely declarative knowledge and procedural knowledge that will help students (Wahyuni \& Prabowo, 2020; Arnita \& Kusrini, 2014; Safitri et al., 2012; Sultan \& BTrip, 2017). From this explanation, this research aims to produce a direct learning model with a life-based learning approach that is feasible, practical, and effective to improve the learning outcomes, of course, students in Morris Sidoarjo.

\section{RESEARCH METHOD}

\section{General Background}

This study uses the Dick and Carey (2009) development model. The research design used the research design The One Group Pretest-posttest Design. The learning model applied in this development uses direct learning with a life-based learning approach. The direct learning model with the life-based learning approach above has five stages in its application, namely

$\checkmark$ conveying goals and motivating, students' orientation of the capabilities and preparations of students,

$\checkmark$ presenting knowledge or demonstrating skills by introducing various learning sources,

$\checkmark$ giving Guided training with the development of students' capabilities (self-directed, continuous inquiry, adaptability, and sustainability),

$\checkmark$ checking to understand and providing feedback and evaluation,

$\checkmark$ providing opportunities for training, application, recognition, and appreciation.

Then the schematic design flowchart of the Dick and Carey learning model development is in the Figure 1 below: 


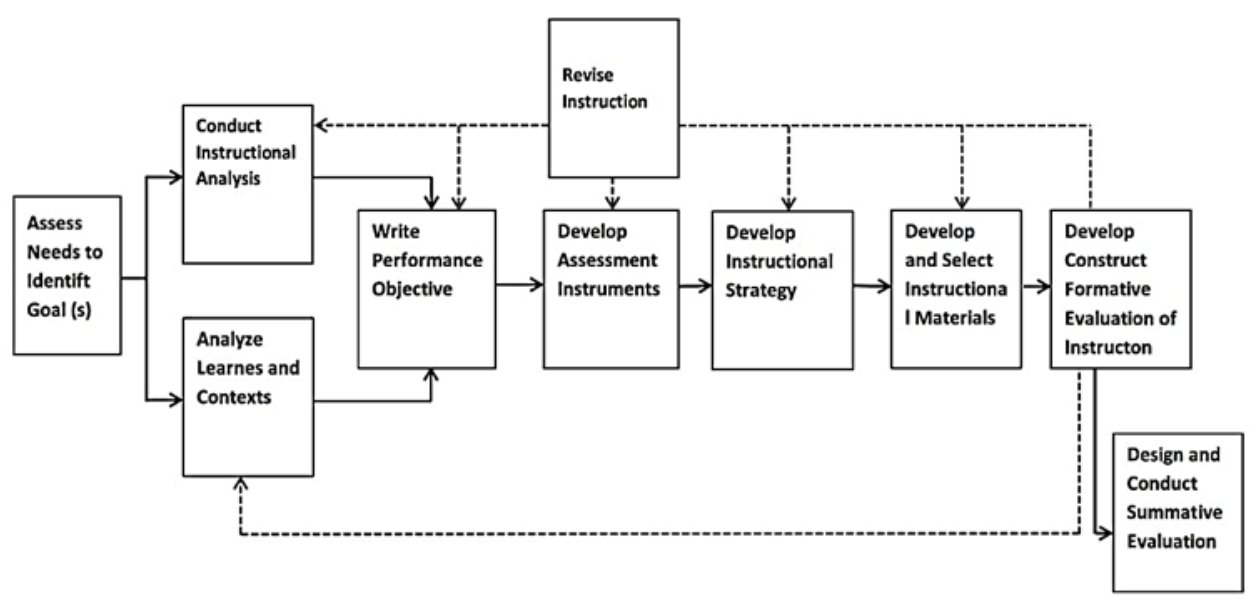

Figure 1. Flowchart of the Dick and Carey Development Design Data Collection

\section{Data Collection}

The data collection process was carried out using observation, questionnaires, and giving tests to students. The research instruments obtained were student activity questionnaires, student response questionnaires, learning observation sheets, and student learning outcomes tests. The research was tested on 20 students at the Morris Sidoarjo course and training institute.

\section{Data Analysis}

\section{Practicality of Direct Learning Model with Life Based Learning Approach a. Learning Implementation}

The analysis of the implementation of the direct teaching model with a life-based learning approach is carried out every time a trained observer is prepared to operate the observation sheet properly. Based on the average assessment of the two observers for the observed aspects, the categories were determined with the details of not good (0 -1), not good (1,1-2), quite good (2,1$3)$, good $(3,1-4)$. The percentage scale for determining the implementation of the RPP uses the following formula:

Average value $\%=\frac{\sum \text { Total Score of each learning activity }}{\sum \text { Total Maximum score }} 100 \%$

\section{b. Analysis of Student Activity}

Assessment is carried out by observing the class each time it is face to face. Observations are made by two observers who have been trained so that they can operate the observation sheet correctly. Based on the average assessment of two observers for each category observed, for each lesson plan the percentage $(\mathrm{P})$ will be determined with the equation:

$P=[$ (Average of two observations) $/$ (Number of Observations) $] \times 100 \%$

\section{Effectiveness of Direct Learning Model by Using Life-Based Learning Approach}

Analysis of test results is used to compare the acquisition of learning outcomes of students who use the direct learning model with the life-based learning approach and students who do not use the direct learning model with the life-based learning approach through the learning outcomes test obtained in the pretest and posttest. Then calculated using the N-Gain test. The calculation of the normalized gain score (N-Gain) can be stated in the following formula:

$\mathrm{g}$ = posttest score - pretest score/maximum score - pretest score

The calculation results are interpreted using normalized gain according to Hake's (1998) classification as follows: 
Table 1. Score Gain Criteria

\begin{tabular}{cc}
\hline Average Gain Score & Category \\
\hline$(\mathrm{g}) \geq 0.7$ & High \\
\hline $0.3 \leq(\mathrm{g})<0.7$ & Moderate \\
\hline$(\mathrm{g})<0.3$ & Low \\
\hline
\end{tabular}

\section{Procedure of Research}

The research procedure was carried out by developing a direct learning model with a life-based learning approach that would be applied to classroom learning. Before applying all learning tools into the classroom, it is necessary to check the validity of the research instrument. The instrument validity test was carried out by 2 expert experts and all research instruments were declared valid. After the learning tools were developed and validity testing by 2 experts, then the initial trials were carried out. The following table shows the results of the assessment of instrument validity by 2 expert experts.

Table 2. Validity of Research Instrument

\begin{tabular}{|c|c|c|}
\hline No. & Expert & Average \\
\hline 1 & Learning design I & 3.8 \\
\hline 2 & Learning design II & 3.9 \\
\hline 3 & Material I & 3.6 \\
\hline 4 & Material II & 3.9 \\
\hline \multirow[t]{2}{*}{5} & Evaluation & 4 \\
\hline & Total Average & 3.8 \\
\hline
\end{tabular}

\section{RESULT AND DISCUSSION}

\section{A. Practicality of Direct Learning Model with Life based learning approach}

After the product has been internally validated and declared valid and revised based on the input and suggestions submitted by the validator, the resulting product is ready for external validation (testing in class to see practicality). The trial collects data regarding the opinions of students regarding the use of the learning model that has been developed, but this trial is carried out like a learning simulation and is assessed in terms of the use of the learning model in terms of students and educators. In the implementation of external validation, an educator activity questionnaire sheet was given to one educator as a practitioner and a student activity questionnaire sheet for 20 students at Morris Sidoarjo in the Yogyakarta bridal make-up course program.

\section{Educator activity questionnaire results}

The results of the practicality test (teacher activity) are in the form of the results of filling out a questionnaire for the implementation of learning by the observer as shown below.

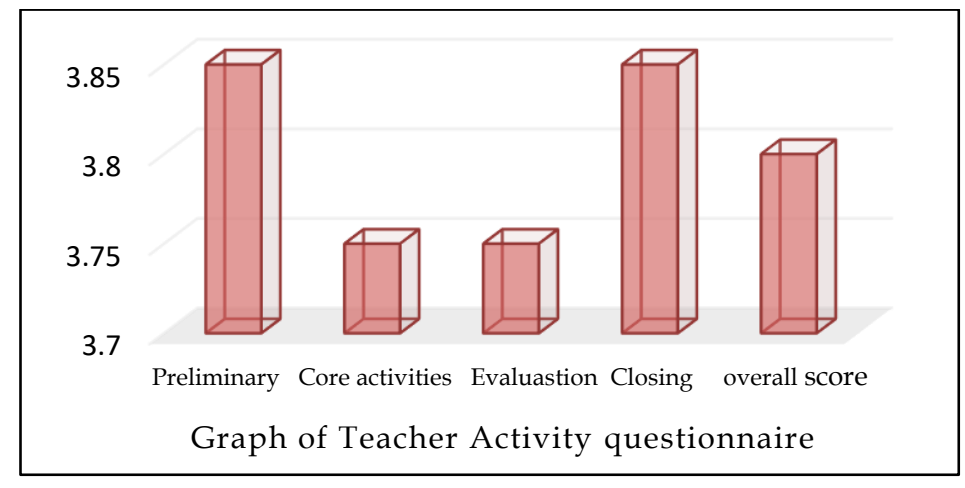

Figure 2. Results of the Teacher Activity Questionnaire

Based on Figure 2, the results of the questionnaire on the implementation of the learning model above obtained an overall mean of 3.8 with the good category. Based on these values, the activities 
by educators in learning meet practical criteria. In line with Nur and Syampurna's research (2019) that the direct learning process goes well and is categorized well.

\section{The results of the student activity questionnaire}

The results of the practicality test (student activities) are in the form of the results of filling out a questionnaire for the implementation of learning by students as in the table below.

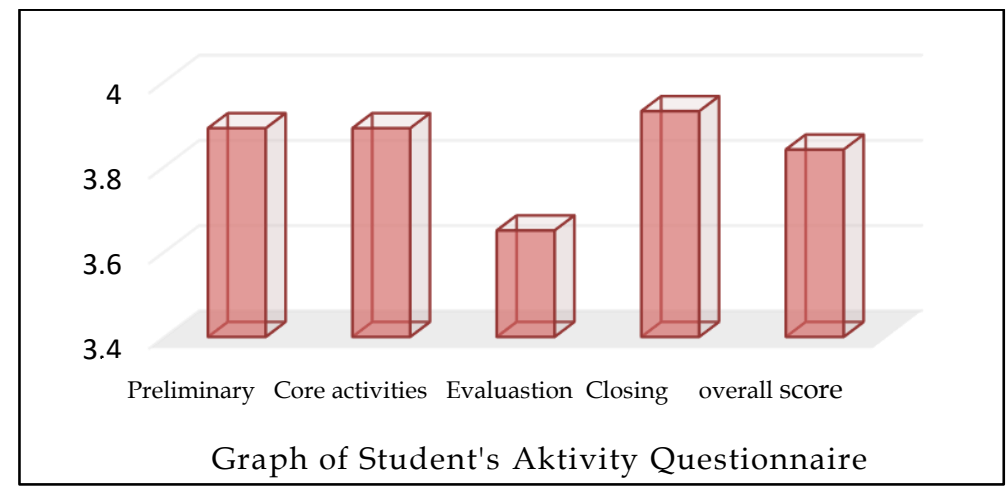

Figure 3. Results of the Student's Activity Questionnaire

Based on the questionnaire results for the implementation of the learning model above, the overall mean was 3.84 in the good category. Based on these values, the activities of students in learning meet the Practical criteria. Thus, the direct learning model with a practical life-based learning approach in improving the learning outcomes of course participants in Morris Sidoarjo in the Yogyakarta bridal make-up course program.

Learning with a life-based learning approach is whole learning that is interrelated so that it is not easy to separate. By walking carefully with the environment or following environmental developments, a way of thinking is formed in each individual (Mubarok et al., 2020). Learning with a life-based learning approach comes from several learning sources that open opportunities to develop individual abilities (Staron, 2011). The life-based learning model is the key to changing and developing a new ecology of learning in make-up courses. The life-based learning model can be used as feedback to implement learning make-up courses that are increasingly contextualintegrative-holistic. This learning can also improve students' skills in finding work (Lyer, 2017; Fawait, 2017).

In the knowledge era, learning activities change from different segmental activities to integrated and interconnected activities. The life-based learning model focuses more on selfdirected learning, continuous inquiry, adaptability, and sustainability (Staron, 2011). Nordin et al. (2020) stated that learning with a focus on everyday life skills will be easier to integrate into learning. Ability in life skills is needed in many fields (Abney \& Wagman, 2015), including work, further education, home and family, vacation, health, community involvement (Jacobs et al., 2012), interpersonal relationships personal development. Supported by Saragih \& Elvis (2015) states that the direct learning process can provide a complete understanding of students. Learning that is taught step by step will provide a good understanding of student activities in the classroom (Astutik, 2010).

\section{B. Effectiveness of Direct Learning Model with Life based learning approach}

To determine the effectiveness of using a direct learning model with a life-based learning approach in improving learning outcomes, it is calculated using the N-Gain test. The N-Gain data analysis was carried out to see the effectiveness of the direct life-based learning model in improving learning outcomes in the Yogyakarta bridal make-up course program. This increase was taken from the pretest and posttest scores obtained by students. Analysis of the assessment of student learning outcomes in Yogyakarta bridal make-up material without wearing a veil can be seen in the following figure. 


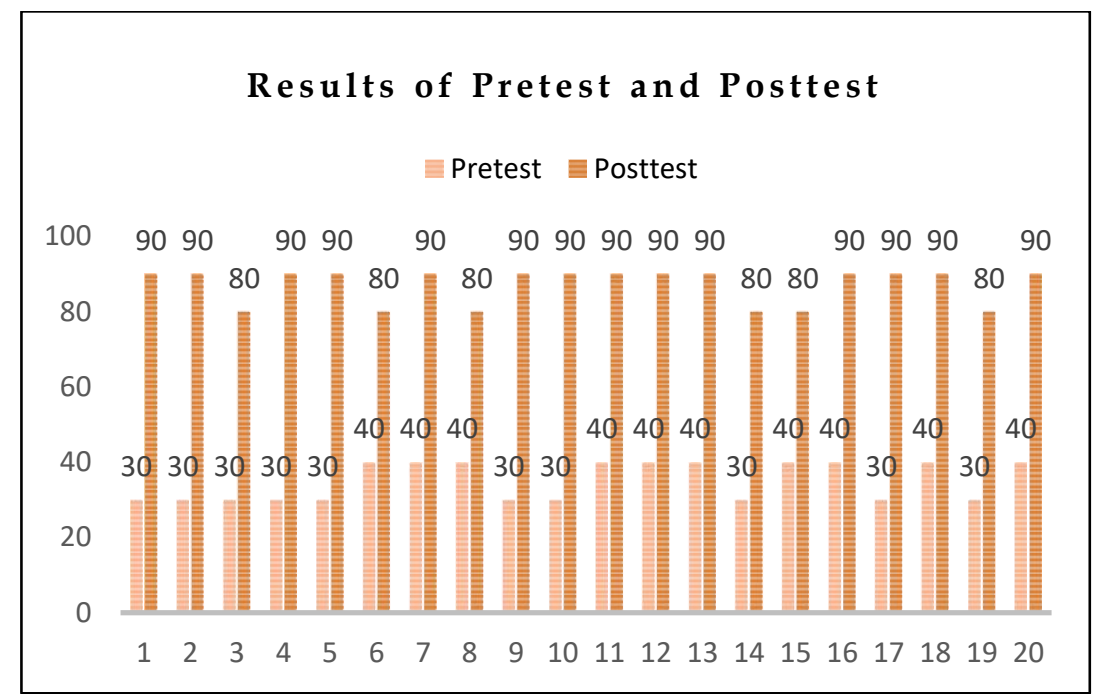

Figure 4. Value of Pretest and Posttest

Based on the graph above, of the 20 student respondents all experienced an increase in learning outcomes from low pretest scores to high posttest scores. The average pretest score has a score ranging from 30-40. After being given treatment using a direct teaching model with a lifebased learning approach, the results of students' scores have increased, ranging from 80-90 scores. Through life-based learning, it can increase the imagination and learning outcomes of students in learning (Bakare \& Orji, 2019; Cheung \& Hew, 2011; Daniel et al., 2010). From the graph of the increase in the pretest and posttest values, it can be seen that the increase in the N-Gain value of all responses in the graph below can be seen.

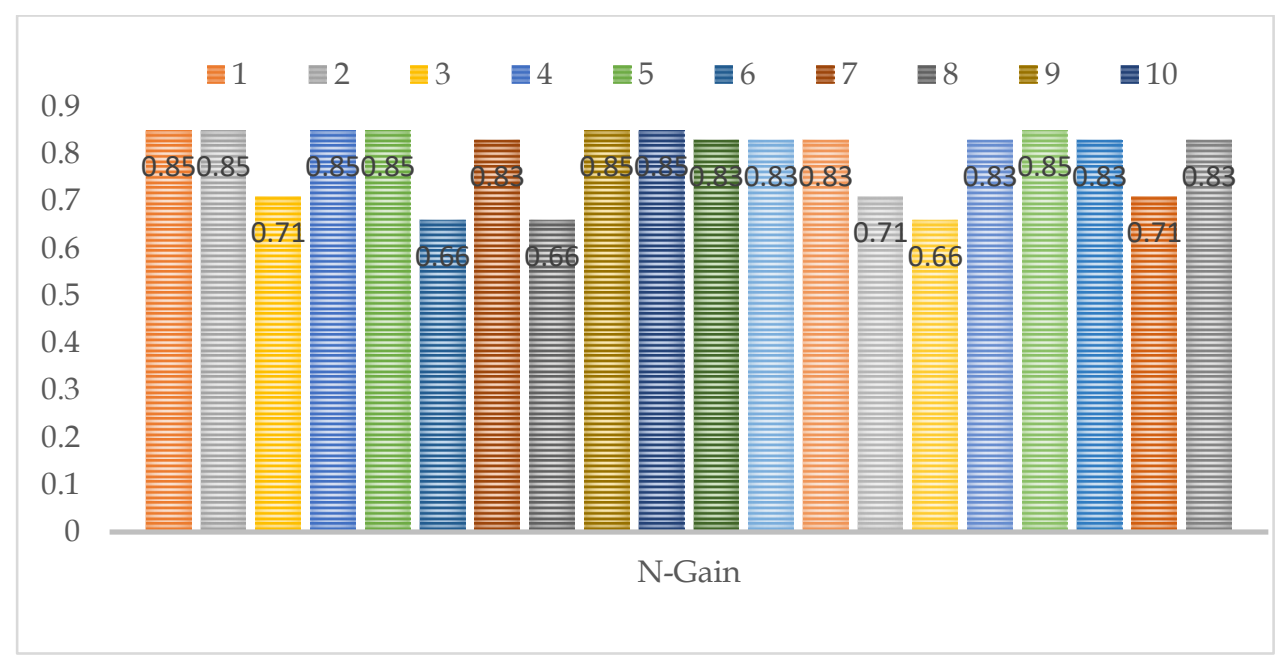

Figure 5. Graph of N-Gain Score

Based on the graph above, we can see that the N-Gain score of each student ranges from 0.66 to 0.85 with each category being medium and high. The value obtained by students after learning with a direct learning model with a life-based learning approach experienced a change in value from pretest to posttest. Furthermore, the value obtained is analyzed to find the average learning outcome, gain, and N-Gain, as follows:

Tabel 3 Average Learning Outcomes of Students

\begin{tabular}{ccccc}
\hline Pretest & Posttest & Gain & N-Gain & Interprestasi N-Gain \\
\hline 35 & 87 & 52 & 0,8 & Tinggi \\
\hline
\end{tabular}


Based on the calculation of Table 3 above, it is known that the pretest average learning outcomes of students before learning with a direct learning model with a life-based learning approach is 35 , then there is an increase in the average posttest learning outcomes after being given treatment with a direct learning model with a life-based approach learning becomes 87 . Direct learning has a high impact on student activity (Irene et al., 2019). Furthermore, based on the results of the N-Gain test calculation, it shows an increase in learning outcomes with a value of 0.8. This increase was also supported by Nur \& Syampurna (2019) that giving direct learning treatment was able to increase students 'pretest scores and improve students' basic abilities. Based on these calculations' results, the Meltzer score (2002) is categorized as high if faced with the criteria. Thus, it can be concluded that the increase in posttest learning outcomes of students who use a direct learning model with a life-based learning approach is higher than the pretest learning outcomes of students who do not use a direct learning model with a life-based learning approach. The direct learning model with a life-based learning approach is stated to have increased effectiveness in learning. Through life-based learning, it can provide a good imagination in every learning process (Abney et al., 2015).

\section{CONCLUSION}

Based on the research, it can be concluded that:

1) the direct learning model with a life-based learning approach is said to be practical in its use to improve the learning outcomes of course participants at Morris Sidoarjo in the Yogyakarta bridal make-up course program, which is shown by the good categories of learning and activity of students,

2) the direct learning model with a life-based learning approach effectively improves the learning outcomes of course participants at Morris Sidoarjo in the Yogyakarta bridal make-up course program. It is as shown by the results of the calculation of the N-Gain test showing an increase in learning outcomes with a value of 0.8 in the high category.

This research is only limited to developing a direct learning model with a life-based learning approach in the course program of veiled bridal make-up without make-up. For future research on the developed learning model, it needs to be trialled in schools or other course institutions with various conditions. It is by the context of students and the school environment, which is different from conducting research.

\section{ACKNOWLEDGEMENTS}

The research team thanks all those who have helped carry out direct learning in this lifebased learning approach.

\section{REFERENCES}

Abdi, A. (2014). The effect of inquiry-based learning method on students' academic achievement in science course. University Journal Educations Research, 2(1), 37-41. https://doi.org $10.13189 /$ ujer.2014.020104

Abney, D. H., \& Wagman, J. B. (2015). Direct learning in auditory perception: An informationspace analysis of auditory perceptual learning of object length. Ecological Psychology, 274, 335-356. https:// doi.org/10.1080/10407413.2015.1086234

Aditomo, A., \& Klieme, E. (2020). Forms of inquiry-based science instruction and their relations with learning outcomes: Evidence from high and low-performing education systems. International Journal of Science Education, 42(4), 504-525. https://doi.org/10.1080/09500693.2020.1716093

Agrippa, K., Dehop, S., Makaliwe, N., \& Makaliwe, N. (2020). Penerapan model pembelajaran langsung untuk meningkatkan hasil belajar siswa pada mata pelajaran IPS Terpadu kelas IX SMP N 1 Tatapaan. Jurnal Pendidikan Ekonomi, 5(2), 275-287. 
Al-Faki, I. M., \& Khamis, A. H. A. (2014). Difficulties facing teachers in using interactive whiteboards in their classes. American International Journal of Social Sciences, 3(2), 136-158.

Arnika, D., \& Kusrini. (2014). Penerapan model pembelajaran langsung (direct instruction) dengan metode kumon pada materi persamaan lingkaran Di SMAN-1 Krian. MathEdunesa, 1(3), 1-6.

Arsyad, A. (2017). Media pembelajaran. Rajawali Pers.

Astutik, E. Y. (2020). Penerapan model pembelajaran langsung (direct instruction) pada kompetensi dasar perawatan kulit wajah secara manual Di SMK Negeri 3 Kediri. E-Jurnal, 9(4), 82-90.

Azwar., Surya, E., \& Saragih, S. (2017). Development of learning devices based on contextual teaching and learning model based on the context of Aceh cultural to improve mathematical representation and self-efficacy ability of SMAN 1 Peureulak Students. Journal of Education and Practice, 8(2), 186-195.

Bakare, J., \& Orji, C. T. (2019). Effects of reciprocal peer tutoring and direct learning environment on sophomores' academic achievement in electronic and computer fundamentals. Education Information Technology, 24, 1035-1055. https:// doi.org/10.1007/s10639-018-9808-1

Cheung, W. C., \& Hew, K. F. (2011). Design and evaluation of two blended learning approaches: Lessons learned. Australian Journal of Educational Technology, 8, 1319-1337. https://doi.org/10.14742/ajet.896

Daniell, C. A., \& Dina, G. M. (2020). The life sciences learning center: an evolving model for a sustainable STEM outreach program. Journal STEM Outreach, 3(2), 1-23. https://doi.org/10.15695/jstem/v3i2.08

Fatmawati, Fayanto. S., Sukariasih, L., \& Retnawati, H. (2019). Investigating the effectiveness of inquiry learning and direct learning models toward physics learning. Advances in Social Science, Education and Humanities Research, 317, 260-265. https:/ / doi.org/10.2991/iconprocs$\underline{19.2019 .54}$

Fawait, A. (2017). Life-Based Learning Dengan Menggunakan Pendekatan Living Value Instruction Dalam Tradisi Akademik Pesantren. 1st Annual Conference for Muslim Scholars. 698-707.

Gutierrez, E. (2015). MOOC \& B-learning: Students' Barriers and Satisfaction in Formal and Nonformal Learning Environments. Journal of Interactive Online Learning, 13(3), 88-111.

Hairida, H. (2018). The Development of Blended Learning Media for Flipped Classroom Model on Direct Learning in Process Evaluation Courses and Chemistry Learning Outcomes. Advances in Social Science, Education and Humanities Research, 295, 211-217. https://doi.org/10.2991/icetep-18.2019.52

Hairida. (2017). Keterampilan calon guru kimia dalam mengembangkan alternative assessment. Jurnal Pengajaran MIPA, 22(1), 1-7. https:// doi.org/10.18269/jpmipa.v22i1.8381

Hamka, L., \& Arsyad. M. N. (2016). Keefektifan penerapan model pembelajaran langsung pada materi sistem gerak di SMA Negeri 1 Donri-Donri. Jurnal Bionature, 16(1), 58-64. https://doi.org/10.35580/bionature.v16i1.1571

Huet, M., Jacobs, D. M., Camachon, C., Missenard, O., Gray, R., \& Montagne, G. (2011). The education of attention as explanation of variability-of-practice effects: Learning the final approach phase in a flight simulator. Journal of Experimental Psychology: Human Perception and Performance, 37, 1841-1854. https:// doi.org/10.1037/a0024386

Ilmika, C. F. (2017). Penerapan model pembelajaran langsung pada kompetensi penataan sanggul pusung Tagel Di SMK Negeri 3 Blitar. Jurnal Tata Rias Jurnal, 3(6). 
Irene, R., Sixto, G. V., Javier, F. R \& Natalia, M. A. (2019). Physical activity levels, game performance and friendship goals using two different pedagogical models Sport Education and Direct Instruction. Physical Education and Sport Pedagogy, 24(1), 87-102. https://doi.org/10.1080/17408989.2018.1561839

Jacobs, D. M., Vaz, D. V., \& Michaels, C. F. (2012). The learning of visually guided action: An information-space analysis of pole balancing. Journal of Experimental Psychology: Human Perception and Performance, 38, 1215-1227. https://doi.org/10.1037/a0027632

Jatmiko, B., Prahani, B. K., Munasir, Supardi, Z. A. I., Wicaksono, I., Erlina, N., Pandiangan, P., Althaf, R., and Zainuddin. (2018). The comparison of OR-IPA teaching model and problem based learning model effectiveness to improve critical thinking skills of pre-service physics teachers. Journal of Baltic Science Education, 17(2), 1-22. http://oaji.net/articles/2017/9871523527582

Lecun, Y., Bengio, Y., \& Hinton, G. (2015). Deep learning. Nature, 521, 436-444. https://doi.org/10.1038/nature14539

Lyer, R. B. (2017). Value-based education: professional development vital towards effective integration. Journal of Research $\mathcal{E}$ Method in Education, 1(1), 17-20. https:// doi.org/10.9790/7388-0111720

Miller, D. R. (2008). Life Based Learning: Designing professional development for the knowledge era.

Australia.

(Online). https://www.vcihome.com/sites/PDF_files/PPT_knowledgeera.pdf

Mubarok, H., Safitri, N. S., \& Adam , A. S. (2020). The Novelty of Religion and Art: Should We Combine with STEM Education?. Studies in Philosophy of Science and Education, 1(3), 97-103. https://doi.org/10.46627/sipose.v1i3.51

Nordin, L., Razak, N. Z. A., \& Kassim, R. (2020). Direct learning strategies employed in learning english among students of engineering technology. Journal of Critical Reviews, 7(8), 162-167. https;//doi.org/10.31838/jcr.07.08.33

Nur, H. J., \& Syampurna, H. (2019). The effect of direct learning models in improving mastery of sepaktakraw basic techniques. Jurnal Performa Olahraga,4(01), 29-39. https://doi.org/10.24036/po.v4i01.70

Rachman, F. (2015). Pengembangan perangkat pembelajaran dasar dan pengukuran listrik dengan media circuit wizard menggunakan model pembelajaran langsung (Direct Instructions) berbasis kurikulum 2013. Jurnal Pendidikan Teknik Elektro, 14(2), 469-476.

Safitri, I., Hartono, B., Halimah, H., 2013. Penerapan multiple intelligences melalui model pembelajaran langsung terhadap sikap dan hasil belajar kimia peserta didik di SMA Negeri 1 Tellu Limpoe. Jurnal Pendidikan IPA Indonesia, 2(2), 156-160. https://doi.org/10.15294/jpii.v2i2.2717

Saragih, S., \& Elvis, N. (2015). Developing student-centered learning model to improve high order mathematical thinking ability. International Education Studies, 8(6). https://doi.org/10.5539/ies.v8n6p104

Setiawan, B. (2020). The anxiety of educational reform and innovation: Bridging of top-down and bottom-up strategies within practice educational reform of curriculum in Indonesia. Studies in Philosophy of Science and Education, 1(2), 87-96. https:// doi.org/10.46627/sipose.v1i2.30

Staron, M. (2011). Life based learning model-a model for strength-based approaches to capability development and implications for personal development planning. TAFE NSW International Centre for VET Teaching and Learning. 1-14. 
Sultan, A. D., \& Bancong, H. (2017). Pengaruh pendekatan multiple intelligences melalui model pembelajaran langsung terhadap sikap dan hasil belajar fisika peserta didik kelas XI IPA SMA Negeri 11 Makassar. Jurnal Pendidikan Fisika, 5(1), 50-60.

Wahyuni, E., \& Prabowo. (2020). Validitasi perangkat pembelajaran model direct instruction berbantu KIT EHUS20 pada materi elastisitas. Inovasi Pendidikan Fisika, 9(1), 18-20.

Yan, H., Wan, J., Zhang, C., Tang, S., Hua, Q., \& Wang, Z. (2018). Industrial big data analytics for prediction of remaining useful life based on deep learning. IEE Access, 6, 17190-17197.

Author (s) :

* Annita Kastur (Corresponding Author)

Universitas Negeri Surabaya, Indonesia

Jl. Raya Kampus Unesa, Lidah Wetan, Kec. Lakarsantri, Kota Surabaya, Jawa Timur 60213 Indonesia

Email: annitakastur16070996008@mhs.unesa.ac.id

Mustaji

Universitas Negeri Surabaya, Indonesia

Jl. Komplek Universitas Negeri Surabaya Gedung D1, J1. Ketintang Sel. No.Kel, Ketintang, Kec. Gayungan, Kota Surabaya, Jawa Timur 60231 Indonesia

Email: mustaji@unesa.ac.id

Yatim Riyanto

Universitas Negeri Surabaya, Indonesia

Jl. Komplek Universitas Negeri Surabaya Gedung D1, Jl. Ketintang Sel. No.Kel, Ketintang, Kec. Gayungan, Kota Surabaya, Jawa Timur 60231 Indonesia

Email: yatimriyanto@unesa.ac.id 